\title{
Hubungan Self Efficacy Akademik dengan Prokrastinasi Akademik pada Mahasiswa yang Sedang Menyelesaikan Skripsi
}

\author{
Annisa Rosni Zusya, Sari Zakiah Akmal \\ Universitas YARSI, Jl. Letjend Suprapto Kav 13 Jakarta \\ e-mail: annisa.rosni37@gmail.com
}

\begin{abstract}
Having graduated not at the right time is a common phenomena among college students and procrastinantion which is delaying the final assignment become the reason. One of factors that affect procrastination is self-efficacy. Self-efficacy that is predicting academic achievement is academic self-efficacy. This research uses quantitative methods to examine the relationship between academic self-efficacy and academic procrastination among 210 students who are completing the last assignment. Instrument used are academic procrastination scale and academic self-efficacy scale. Result shows that there is no significant correlation between academic self-efficacy and academic procrastination among students who were completing the last assignment $(r=-0.059, p=0.398)$. Besides, academic procrastination had significant differences by age, gender, year of admission, residence, and activities. In the same time, the academic self-efficacy had differences by age, year in, obstacles and activities.
\end{abstract}

Keywords: academic self efficacy, academic procrastination, final assignment

\begin{abstract}
Abstrak
Lulus tidak tepat waktu sering ditemui di kalangan mahasiswa dan salah satu penyebabnya adalah penundaan pengerjaan tugas akhir yang disebut prokrastinasi. Salah satu faktor yang dapat mempengaruhi prokrastinasi adalah self efficacy. Self efficacy yang spesifik memprediksi pencapaian akademik adalah self-efficacy akademik. Penelitian ini menggunakan metode kuantitatif untuk melihat hubungan self efficacy akademik dengan prokrastinasi akademik pada 210 mahasiswa yang sedang menyelesaikan skripsi. Penelitian ini menggunakan alat ukur Academic Procrastination Scale dan Academic Self Efficacy. Berdasarkan uji korelasi ditemukan tidak terdapat hubungan yang signifikan antara self efficacy akademik dengan prokrastinasi akademik pada mahasiswa yang sedang menyelesaikan skripsi $(\mathrm{r}=-0,059, \mathrm{p}=$ 0,398). Berdasarkan perhitungan uji beda yang dilakukan prokrastinasi akademik memiliki perbedaan yang signifikan berdasarkan usia, jenis kelamin, tahun masuk, tempat tinggal, dan kegiatan. Sedangkan untuk self efficacy akademik memiliki perbedaan berdasarkan usia, tahun masuk, hambatan dan kegiatan.
\end{abstract}

Kata Kunci: self-efficacy akademik, prokrastinasi akademik, mahasiswa, skripsi

\section{Pendahuluan}

Berdasarkan data yang didapatkan dari bagian tata usaha Fakultas Psikologi Universitas YARSI tahun 2015, pada tiap tahunnya terdapat lebih dari $50 \%$ mahasiswa yang lulus tidak tepat waktu (lebih dari 4 tahun). Di angkatan 2007 berjumlah $75 \%$ (dari 24 orang), angkatan 2008 terdapat $60 \%$ (dari 15 orang), angkatan 2009 terdapat $61 \%$ (dari 36 orang), angakatan 2010 terdapat $72 \%$ (dari 66 orang), dan angkatan 2011 terdapat $72 \%$ (dari 61 orang). Salah satu penyebab kelulusan yang tidak tepat waktu adalah adanya penundaan pengerjaan tugas akhir (Fibrianti, 2009). Menurut Siaputra (2012) penundaan tugas akhir dapat disebabkan oleh beberapa hal, diantaranya adalah sikap kurang disiplin mahasiswa (tidak mengikuti atau telat bimbingan skripsi sesuai dengan jadwal yang telah ditentukan), dosen pembimbing yang sulit ditemui, tidak mendapatkan persetujuan dari dosen pembimbing (misalnya, judul skripsi tidak disetujui oleh dosen pembimbing, 
perbaikan yang diberikan tidak memuaskan), sulit mencari literatur terkait dengan skripsi (sulit mencari jurnal, buku referensi) dan sebagainya.

Perilaku menunda pengerjaan dan penyelesaian sesuatu disebut dengan prokrastinasi. Orang yang melakukan perilaku menunda disebut penunda (prokrastinator). Gejala perilaku menunda (prokrastinasi) lebih banyak dimanifestasikan dalam dunia pendidikan yang sering disebut dengan prokrastinasi akademik (Solomon dalam Khusniatun, 2014). Prokrastinasi akademik menurut McCloskey (2011) adalah kecenderungan untuk menunda-nunda aktivitas yang berhubungan dengan belajar di lingkungan akademik.

Konsekuensi dari prokrastinasi akademik adalah performa yang kurang, mutu kehidupan individu berkurang, pengaruh negatif (menambah beban pikiran, mudah tertekan, tidak percaya diri dan cemas) dan menurunnya prestasi (Ferrari dalam Schouwenburg \& Dewitte, 2002). Prokrastinasi dalam penyusunan skripsi dapat berdampak pada mahasiswa, seperti: waktu yang terbuang sia-sia, hasil yang tidak maksimal, kurangnya performa dalam menyelesaikan skripsi, hingga kecenderungan untuk tidak menyelesaikan skripsi (Yesil, 2012 dalam Fitriani, 2016). Kelulusan yang tidak tepat waktu dapat merugikan mahasiswa sendiri, terutama dari faktor pembiayaan, ketersediaan waktu dan tenaga untuk mengerjakan skripsi. Selain itu, kelulusan tidak tepat waktu juga menjadi masalah bagi fakultas karena dapat mempengaruhi penilaian akreditasi.

Pada dasarnya, mahasiswa me-nyadari dampak negatif dari prokrastinasi akademik namun mereka tetap me-lakukannya (Steel, 2007), karena perilaku tersebut sudah menjadi kebiasaan sejak di bangku sekolah. Prokrastinasi akademik dipengaruhi oleh dua faktor, yaitu: faktor internal dan eksternal. Faktor internal merupakan faktor yang berasal dari dalam dir individu, meliputi kepercayaan diri, kontrol diri, self- efficacy, motivasi, regulasi diri, kesadaran diri dan self-critical. Faktor eksternal merupakan faktor yang berasal dari luar diri individu yang ikut menyebabkan terjadinya kecenderungan terjadinya prokrastinasi akademik, meliputi gaya pengasuhan orangtua dan kondisi lingkungan (Ferrari dalam Rahmawati, 2011). Pada penelitian yang dilakukan Steel (2007) self-efficacy memiliki peranan cukup penting dalam dinamika kemunculan prokrastinasi. Adannya keyakinan dalam diri dan harapan keberhasilan yang tinggi membuat seseorang memiliki keinginan yang tinggi untuk mencapai tujuannya, sehingga tingkat prokrastinasi rendah dan sebaliknya.

Penelitian mengenai kaiatan antara self-efficacy dan prokrastinasi sudah pernah dilakukan. Penelitian yang dilakukan Rohmatun (2013) dan Julianda (2012) menunjukkan bahwa terdapat hubungan negatif antara self-efficacy dengan prokrastinasi akademik pada mahasiswa. Hal ini berarti, semakin tinggi self-efficacy mahasiswa maka semakin rendah kecenderungan mereka dalam melakukan prokrastinasi akademik. Penelitian Julianda (2012) menunjukkan bahwa salah satu hal yang menyebabkan mahasiswa melakukan prokrastinasi akademik adalah adanya kecenderungan seseorang memiliki pemikiran yang irasional dalam menilai kemampuan dirinya. Sementara itu, penelitian yang dilakukan oleh Nuruddin (2010) menunjukkan bahwa self-efficacy tidak memiliki hubungan yang signifikan dengan perilaku prokrastinasi akademik. Nuruddin (2010) menyimpulkan bahwa terdapat faktor lain yang lebih mempengaruhi munculnya perilaku prokrastinasi akademik pada mahasiswa. Beberapa hasil penelitian tersebut masih menunjukkan hasil yang belum konsisten mengenai keterkaitan antara self-efficacy dan perilaku prokrastinasi akademik.

Sebuah studi meta analisis dalam skala besar terkait self-efficacy dalam bidang 
akademik mengindikasikan bahwa selfefficacy yang spesifik lebih akurat dalam memprediksi pencapaian akademik pada individu dibandingkan dengan self-efficacy secara umum (Multon, Brown, \& Lent, dalam Zajacova, dkk, 2005). Menurut Zajacova, dkk (2005), academic selfefficacy merupakan keyakinan mahasiswa terhadap kemampuan mereka dalam melaksanakan tugas-tugas akademik seperti mempersiapkan diri untuk ujian dan menyusun makalah. Secara umum selfefficacy tidak dapat memprediksi pencapaian akademik di perguruan tinggi, sementara self-efficacy akademik telah konsisten dalam memprediksi nilai dan ketekunan di perguruan tinggi (Ferrari \& Parker; Lindley \& Borgen, dalam Zajacova, dkk, 2005).

Berdasarkan pemaparan sebelum-nya, dapat disimpulkan bahwa perilaku prokrastinasi akademik umumnya ditemui pada mahasiswa, terutama mahasiswa yang sedang menyelesaikan tugas akhir (skripsi). Perilaku ini muncul karena proses pengerjaan skripsi yang cenderung individual dan menjadi tanggung jawab pribadi serta tidak memiliki batasan waktu yang ketat. Beberapa penelitian terdahulu menunjukkan hasil yang belum konsisten mengenai keterkaitan antara self-efficacy dengan prokrastinasi akademik. Penelitian yang dilakukan oleh Zajacova (2005) menunjukkan bahwa self-efficacy semakin baik jika semakin spesifik. Hal tersebut menjadi ketertarikan penelitin untuk melihat hubungan antara self-efficacy academic dengan prokrastinasi akademik pada mahasiswa yang sedang menyelesaikan skripsi.

\section{Metode Penelitian}

Penelitian ini menggunakan metode penelitian kuantitatif dengan rancangan penelitian asosiatif. Variabel pertama dalam penelitian ini yaitu self-efficacy akademik menggunakan skala Academic
Self-efficacy (ASE) yang disusun oleh Zajacova (2005) dan telah diadaptasi oleh Rauf (2015). Instrumen ASE berbentuk kuesioner yang terdiri dari 27 pernyataan. Kemudian, variabel kedua dalam penelitian ini yaitu prokrastinasi akademik menggunakan skala Academic Procrastination Scale (APS) yang disusun oleh McCloskey (2011). Instrumen APS berbentuk kuesioner yang terdiri dari 24 pertanyaan. Populasi penelitian ini adalah mahasiswa yang sedang menyelesaikan skripsi di Jakarta dengan sampel sebanyak 210 mahasiswa yang sedang menyelesaikan skripsi. Teknik pengambilan sampel penelitian ini menggunakan nonprobability sampling dengan desain insidental sampling. Analisis statistik menggunakan kolmogorov smirnov.

\section{Hasil Penelitian dan Pembahasan}

Tabel 1 memperlihatkan data demografi responden. Mayoritas partisipan dalam penelitian ini berjenis kelamin perempuan $(56,2 \%)$ dan sebagian besar dari partisipan menjadi mahasiswa semenjak tahun 2011 (64,8\%). Partisipan dalam penelitian ini umumnya membutuhkan waktu 6-10 bulan $(62,4 \%)$ dalam menyelesaikan skripsi, dengan hambatan yang paling dirasakan mahasiswa adalah sulitnya mencari literatur terkait dengan skripsinya $(38,1 \%)$. Sebagian besar partisipan $(67,1 \%)$ menyatakan bahwa mereka memiliki orang terdekat yang juga mengalami keterlambatan dalam menyelesaikan skripsi. Selama proses menyelesaikan skripsi, sebagian besar mahasiswa tidak memiliki kegiatan lain yang dilakukan selain menyelesaikan skripsi $(41,0 \%)$. Mayoritas partisipan penelitian $(63,8 \%)$ tinggal bersama orang tuanya. 
Tabel 1. Demografi Responden

\begin{tabular}{|c|c|c|c|}
\hline \multicolumn{2}{|c|}{ Variabel } & \multirow{2}{*}{$\frac{\text { Jumlah }}{92}$} & \multirow{2}{*}{$\begin{array}{c}\text { Persentase } \\
43,8 \%\end{array}$} \\
\hline Jenis Kelamin & Laki-laki & & \\
\hline & Perempuan & 118 & $56,2 \%$ \\
\hline \multirow[t]{4}{*}{ Tahun Masuk } & 2009 & 19 & $9 \%$ \\
\hline & 2010 & 40 & $19,0 \%$ \\
\hline & 2011 & 136 & $64,8 \%$ \\
\hline & 2012 & 15 & $7,1 \%$ \\
\hline \multirow[t]{4}{*}{ Lamanya Skripsi } & 6-10 Bulan & 131 & $62,4 \%$ \\
\hline & 11-15 Bulan & 47 & $22,4 \%$ \\
\hline & 16-20 Bulan & 15 & $7,1 \%$ \\
\hline & 21-26 Bulan & 17 & $8,1 \%$ \\
\hline \multirow[t]{4}{*}{$\begin{array}{l}\text { Hambatan Dalam } \\
\text { Menyelesaikan Skripsi }\end{array}$} & $\begin{array}{l}\text { Kondisi fisik yang kurang } \\
\text { sehat }\end{array}$ & 10 & $4,8 \%$ \\
\hline & $\begin{array}{l}\text { Susah bertemu dengan } \\
\text { dosen pembimbing }\end{array}$ & 76 & $36,2 \%$ \\
\hline & $\begin{array}{l}\text { Susahmencari literatur } \\
\text { terkait dengan skripsi }\end{array}$ & 80 & $38,1 \%$ \\
\hline & Tidak ada & 44 & $21,0 \%$ \\
\hline Kegiatan Selain & Berjualan/Bisnis & 32 & $15,2 \%$ \\
\hline \multirow[t]{4}{*}{ Menyelesaikan Skripsi } & Berkeluarga & 2 & $1,0 \%$ \\
\hline & Berorganisasi & 42 & $20,0 \%$ \\
\hline & Magang/Kerja & 48 & $22,9 \%$ \\
\hline & Tidak Ada & 86 & $41,0 \%$ \\
\hline \multirow[t]{2}{*}{ Tempat Tinggal } & Kost & 76 & $36,2 \%$ \\
\hline & Tinggal dengan orangtua & 134 & $63,8 \%$ \\
\hline Terdapat Orang & Ada & 141 & $67,1 \%$ \\
\hline $\begin{array}{l}\text { Terdekat Yang Telat } \\
\text { Dalam Menyelesaikan } \\
\text { Skripsi }\end{array}$ & Tidak Ada & 69 & $32,9 \%$ \\
\hline
\end{tabular}

Tabel 2

Nilai Ststistik Skala Self-efficacy Akademik dan Prokrastinasi Akademik

\begin{tabular}{lccccc}
\hline N & $\begin{array}{l}\text { Skor } \\
\text { Te- } \\
\text { rendah }\end{array}$ & $\begin{array}{l}\text { Skor } \\
\text { Ter- } \\
\text { tinggi }\end{array}$ & $\begin{array}{l}\text { Nilai } \\
\text { Rata- } \\
\text { rata }\end{array}$ & SD \\
\hline $\begin{array}{l}\text { Self- } \\
\text { efficacy } \\
\text { Akademik }\end{array}$ & 10 & 58 & 261 & 183,3 & 38,58 \\
$\begin{array}{l}\text { Prokrasti- } \\
\text { nasi }\end{array}$ & 10 & 37 & 89 & 65,14 & 12,06 \\
Akademik & & & & & \\
\hline
\end{tabular}

Dari tabel 2 dapat diketahui bahwa skor terendah self-efficacy akademik adalah 58 dan skor tertinggi akademik adalah 261 dengan rata-rata 183,3 dan standar deviasi 38,58. Sementara itu, skor terendah prokrastinasi akademik adalah 37 dan skor tertinggi prokrastinasi akademik 89 dengan rata-rata 65,14 dan standar deviasi 12,06.
Tabel 3

Kategorisasi Skala Self-efficacy Akademik

\begin{tabular}{llll}
\hline $\begin{array}{l}\text { Rentang } \\
\text { Nilai }\end{array}$ & Kategorisasi & Jumlah & Persentase \\
\hline $\mathbf{0 - 8 9}$ & Rendah & 8 & $3,9 \%$ \\
$\mathbf{9 0 - 1 7 9}$ & Sedang & 77 & $36,6 \%$ \\
$\mathbf{1 8 0 - \mathbf { 2 7 0 }}$ & Tinggi & 125 & $59,5 \%$ \\
& Jumlah & $\mathbf{2 1 0}$ & $\mathbf{1 0 0 \%}$ \\
\hline
\end{tabular}

Berdasarkan kategorisasi pada tabel 3 diperoleh data mayoritas subjek $(59,5 \%)$ memiliki tingkat self-efficacy akademik yang tinggi.

Tabel 4

Kategorisasi Skala Prokrastinasi Akademik

\begin{tabular}{llll}
\hline $\begin{array}{l}\text { Rentang } \\
\text { Nilai }\end{array}$ & Kategorisasi & Jumlah & Persentase \\
\hline $\mathbf{2 4 - \mathbf { 4 8 }}$ & Rendah & 17 & $8,09 \%$ \\
$\mathbf{4 9 - 7 2}$ & Sedang & 120 & $57,14 \%$ \\
$\mathbf{7 3 - 9 6}$ & Tinggi & 73 & $34,77 \%$ \\
JUMLAH & & $\mathbf{2 1 0}$ & $\mathbf{1 0 0 \%}$ \\
\hline
\end{tabular}


Tabel 4 memperlihatkan data mayoritas subjek $(57,14 \%)$ memiliki tingkat prokrastinasi akademik yang sedang.

Tabel 5

Uji Normalitas Data

\begin{tabular}{lll}
\hline Variabel & K-SZ & $\begin{array}{c}\text { Sig } \\
\text { (2-tailed) }\end{array}$ \\
\hline Self-efficacy akademik & 1,302 & 0,067 \\
Prokrastinasi Akademik & 1,305 & 0,066 \\
\hline
\end{tabular}

Test distribution is Normal.

Dari hasil uji normalitas diperoleh bahwa nilai signifikansi untuk self-efficacy akademik sebesar $0,067 \quad(\mathrm{p}>0,05)$ sedangkan variabel prokrastinasi akademik diperoleh nilai signifikansi sebesar 0,066 (p $>$ 0,05). Dengan demikian dapat disimpulkan bahwa sebaran data kedua variabel tersebut berdistribusi normal.

Tabel 6

\begin{tabular}{cccc} 
Uji Hipotesis & & & \\
\hline Variabel & $\begin{array}{c}\text { Pearson } \\
\text { Correlation }\end{array}$ & $\begin{array}{c}\text { Sig. } \\
\text { (2-tailed) }\end{array}$ & $\mathbf{N}$ \\
\hline $\begin{array}{c}\text { Self-efficacy } \\
\text { akademik dan }\end{array}$ & & & \\
$\begin{array}{c}\text { Prokrastinasi } \\
\text { akademik }\end{array}$ & $-0,059$ & 0,398 & 210 \\
\hline
\end{tabular}

Pada tabel 6 terlihat bahwa nilai korelasi antara self-efficacy akademik dengan prokrastinasi akademik sebesar $\mathrm{r}=$ 0,059 dan nilai signifikansi $\mathrm{p}=0,398(\mathrm{p}>$ $0,05)$. Nilai signifikansi $\mathrm{p}>0,05$ maka dapat diinterpretasikan $\mathrm{Ha}$ ditolak, yang artinya tidak terdapat hubungan yang signifikan antara self-efficacy akademik dengan prokrastinasi akademik pada mahasiswa yang sedang menyelesaikan skripsi.

Tabel 7

Keterkaitan Self-efficacy Akademik dan Demografis

\begin{tabular}{lll}
\hline Data Demografis & $\mathbf{F}$ & $\mathbf{P}$ \\
\hline Usia & $\mathrm{F}=3,169$ & $\mathbf{p}=\mathbf{0 , 0 0 9 *}$ \\
Jenis Kelamin & $\mathrm{F}=1,121$ & $\mathrm{p}=0,291$ \\
Tahun Masuk & $\mathrm{F}=3,094$ & $\mathbf{p}=\mathbf{0 , 0 2 8} *$ \\
Tempat Tinggal & $\mathrm{F}=0,146$ & $\mathrm{p}=0,703$ \\
Orang Terdekat & $\mathrm{F}=0,141$ & $\mathrm{p}=0,707$ \\
\hline
\end{tabular}

\begin{tabular}{lll}
\hline Telat & & \\
Hambatan & $\mathrm{F}=4,245$ & $\mathbf{p}=\mathbf{0 , 0 0 6 *}^{*}$ \\
Kegiatan & $\mathrm{F}=3,724$ & $\mathbf{p}=\mathbf{0 , 0 0 6}^{*}$ \\
\hline
\end{tabular}

*Signifikan pada level 0,05

Berdasarkan hasil analisis perbedaan self-efficacy akademik ber-dasarkan data demografis diperoleh hasil bahwa terdapat perbedaan yang signifikan self-efficacy akademik berdasarkan usia $(\mathrm{F}=3,169, \mathrm{p}=$ $0,009<0,05)$, tahun masuk $(\mathrm{F}=3,094, \mathrm{p}=$ $0,028<0,05)$, hambatan yang dialami saat menyelesaikan skripsi $(\mathrm{F}=4,245, \mathrm{p}=$ $0,006<0,06$ ), dan kegiatan yang dilakukan saat menyelesaikan skripsi $(\mathrm{F}=3,724, \mathrm{p}=$ 0,006).

Tabel 8

Keterkaitan Prokrastinasi Akademik dan Demografis

\begin{tabular}{lll}
\hline & $\mathbf{F}$ & $\mathbf{P}$ \\
\hline Usia & $\mathrm{F}=3,473$ & $\mathbf{p}=\mathbf{0 , 0 0 5} *$ \\
Jenis Kelamin & $\mathrm{F}=18,31$ & $\mathbf{p}=\mathbf{0 , 0 0 0} *$ \\
Tahun Masuk & $\mathrm{F}=4,962$ & $\mathbf{p}=\mathbf{0 , 0 0 2} *$ \\
Tempat Tinggal & $\mathrm{F}=9,436$ & $\mathbf{p}=\mathbf{0 , 0 0 2} *$ \\
$\begin{array}{l}\text { Orang Terdekat } \\
\text { Telat }\end{array}$ & $\mathrm{F}=2,636$ & $\mathrm{p}=0,106$ \\
Hambatan & $\mathrm{F}=2,336$ & $\mathrm{p}=0,075$ \\
Kegiatan & $\mathrm{F}=2,537$ & $\mathbf{p}=\mathbf{0 , 0 4 1} *$ \\
\hline
\end{tabular}

*Signifikan pada level 0,05

Berdasarkan hasil analisis data demografi dengan skor total prokrastinasi akademik diperoleh hasil bahwa terdapat perbedaan yang signifikan prokrastinasi akademik berdasarkan usia $(\mathrm{F}=3,473, \mathrm{p}=0,005<$ 0,05), jenis kelamin $(\mathrm{F}=18,31, \mathrm{p}=0,000<$ $0,05)$, tahun masuk $(\mathrm{F}=4,962, \mathrm{p}=0,002<$ $0,05)$, tempat tinggal $(\mathrm{F}=9,436, \mathrm{p}=0,002$ $<0,05)$, dan kegiatan yang dilakukan saat menyelesaikan skripsi $(\mathrm{F}=2,537, \mathrm{p}=$ $0,041<0,05)$.

\section{Pembahasan}

Dengan mengacu pada uji hipotesis yang telah dilakukan, maka diketahui bahwa tidak terdapat hubungan yang signifikan antara self-efficacy akademik dengan prokrastinasi akademik pada mahasiswa yang sedang menyelesaikan 
skripsi. Penelitian ini menunjukkan mayoritas mahasiswa memiliki self-efficacy akademik yang tinggi $(59,5 \%)$ dan tingkat prokrastinasi akademik yang sedang $(57,14 \%)$. Hasil penelitian ini sejalan dengan penelitian yang dilakukan Nuruddin (2010) dan menunjukan bahwa self-efficacy akademik tidak memiliki hubungan yang signifikan dengan prokrastinasi akademik. Berdasarkan hasil penelitian yang dilakukan Nuruddin (2010) self-efficacy memberikan sumbangan yang kecil terhadap prokrastinasi akademik, masih terdapat beberapa faktor lainnya (self critical, motivasi, kontrol diri dan penyesuaian diri) yang dapat mempengaruhi tingkat prokrastinasi akademik seseorang. Sokolowska (2009) mengatakan bahwa penyebab individu melakukan prokrastinasi akademik adalah personality based reason (perbedaan karakteristik kepribadian), task related reason (keterkaitan konsep atau tugas) dan ability perception reason (persepsi terhadap kemampuan diri). Faktor-faktor tersebut yang mungkin lebih memiliki hubungan dengan prokrastinasi akademik dibandingkan dengan self-efficacy akademik.

Berdasarkan analisa tambahan terkait data demografi, peneliti melihat perbedaan prokrastinasi akademik berdasarkan usia, jenis kelamin, tahun masuk, tempat tinggal dan kegiatan yang dilakukan selain menyelesaikan skripsi. Berdasarkan usia, responden yang berusia 21 tahun pada umumnya berada di angkatan 2011, memiliki prokrastinasi akademik yang lebih rendah dibandingkan responden yang berusia 23 (angkatan 2010). Hasil ini sejalan dengan penelitian yang dilakukan oleh Ahmaini (2010) yaitu, mahasiswa dengan semester lebih tinggi memiliki prokrastinasi akademik yang tinggi. Mereka lebih sering menunda pekerjaan karena mereka merasa bahwa dirinya sudah terlalu lama dalam menyelesaikan skripsi sehingga menjadikan mereka malas dalam menyelesaikan skripsi (Ahmaini, 2010).
Faktor lainnya yang dapat mempengaruhi prokrastinasi akademik pada mahasiswa yang sedang menyelesaikan skripsi adalah jenis kelamin. Pada penelitian ini mahasiswa yang berjenis kelamin laki-laki memiliki tingkat prokrastinasi akademik yang tinggi dibandingkan dengan mahasiswa perempuan. Fuadi (2013) dalam penelitiannya mengatakan bahwa skripsi merupakan tugas yang berat bagi laki-laki. Selama proses mengerjakan skripsi banyak hal yang harus dilakukan sehingga hal ini terasa berat untuk laki-laki. Hal itu sejalan dengan penelitian Aini (2011) yang menyatakan bahwa laki-laki lebih suka menunda suatu pekerjaan yang dianggap mudah. Sementara itu, jika ada pekerjaan yang sulit laki-laki melihat terlebih dahulu apakah dirinya mampu untuk mengerjakannya atau tidak. Jika dirinya merasa tidak mampu maka mereka akan menunda pekerjaan tersebut sampai batas waktu yang ditentukan, penundaan tersebut disebabkan karena sikap dan karakteristik kepribadian seperti inisiatif (McCloskey, 2011). Fuadi (2013) mengatakan bahwa laki-laki memiliki tingkat inisiatif yang lebih rendah dibandingkan dengan perempuan, karena ketika laki-laki menghadapi suatu tugas mereka cenderung untuk menunda tugas yang diberikan. Individu yang kurang inisiatif tidak memiliki dorongan untuk menyelesaikan tugas tepat waktu. Kurangnya motivasi dan inisiatif merupakan alasan individu melakukan prokrastinasi (Caruth \& Caruth, dalam McCloskey, 2011).

Berdasarkan tempat tinggal mahasiswa selama menyelesaikan skripsi, mahasiswa yang tinggal bersama orangtua memiliki prokrasinasi yang rendah dibandingkan mahasiswa yang tinggal di kostan. Hal itu sejalan dengan penelitian Fibrianti (2009) yang menyatakan bahwa mahasiswa yang tidak tinggal dengan orangtua memiliki prokrastinasi yang tinggi. Hal ini disebabkan karena mahasiswa yang tinggal berjauhan dengan orangtua menjadi lebih 
sulit dikontrol dan lebih bebas dalam mengambil suatu keputusan sehingga dapat memunculkan perilaku prokrastinasi.

Faktor yang mempengaruhi prokrastinasi akademik selanjutnya adalah adanya kegiatan selain menyelesaikan skripsi. Hal itu terlihat mahasiswa yang mengikuti organisasi memiliki tingkat prokrastinasi yang tinggi dibandingkan mahasiswa yang tidak memiliki kegiatan selain menyelesaikan skripsi. Hasil tersebut sejalan dengan penelitian Wibowo (2014) yang menyatakan jika seseorang memiliki banyak kegiatan dan mengikuti organisasi ketika dihadapkan dengan tugas dalam waktu yang bersamaan, maka akan memunculkan perilaku menunda pekerjaan tersebut. Beban tugas yang berbeda-beda tersebut dapat menimbulkan kemalasan untuk mulai mengerjakan tugas yang telah diberikan. Mahasiswa yang mengikuti organisasi saat menyelesaikan skripsi cenderung "meremehkan" perencanaan waktu untuk menyelesaikan suatu tugas dan mahasiswa lebih cenderung untuk melakukan prokrastinasi dibandingkan mahasiswa yang dapat memperkirakan waktu yang dibutuhkan untuk mengerjakan tugas dengan efisien (Wibowo, 2014).

Penelitian ini juga melihat perbedaan self-efficacy akademik berdasarkan usia, tahun masuk, hambatan yang dialami saat menyelesaikan skripi dan kegiatan yang dilakukan selain menyelesaikan skripsi. Berdasarkan usia, responden yang berusia 24 tahun pada umumnya berada di angakatan 2009, memiliki self-efficacy yang lebih rendah dibandingkan responden yang berusia 21 tahun (pada umumnya berada di angkatan 2011). Hasil itu sejalan dengan penelitian yang dilakukan oleh Maslach, Schaufeli, \& Leiter (dalam Rauf, 2015) yaitu, usia merupakan salah satu karakteristik yang paling berhubungan dengan self-efficacy. Individu dengan usia yang lebih muda memiliki self-efficacy yang lebih tinggi. Saat usia muda individu memiliki keyakinan dan kesuksesan yang lebih untuk mencapai segala aktivitas yang dilakukan. Menurut Bandura (1997), pengalaman keberhasilan memberikan pengaruh besar pada self-efficacy individu. Pengalaman keberhasilan akan menaikkan self-efficacy individu sedangkan pengalaman kegagalan akan menurunkannya. Saat usia muda pengalaman kegagalan belum terlalu banyak, hal itu yang menjadikan individu memiliki self-efficacy yang tinggi.

Sulitnya mencari literatur yang terkait dengan skripsi menjadi salah satu faktor yang berperan dalam self-efficacy akademik mahasiswa yang sedang menyelesaikan skripsi. Penelitian ini sejalan dengan penelitian sebelumnya yang menunjukkan bahwa self-efficacy akademik memiliki hubungan dengan hambatan yang dialami mahasiswa yang sedang menyelesaikan skripsi (Julianda, 2012). Julianda (2012) menyatakan bahwa salah satu hambatan yang paling dirasakan mahasiswa yang sedang menyelesaikan skripsi adalah sulitnya mencari literatur. Mahasiswa merasa sulit untuk mengakses literatur yang dicari dan memiliki keterbatasan untuk mencari literatur yang serupa dengan judul skripsi, hal ini yang menyebabkan mahasiswa tidak memiliki keyakinan untuk mecapai keberhasilan dalam proses pengerjaan skripsi (Julianda, 2012).

Adapun faktor lainnya yang mempengaruhi self-efficacy akademik adalah adanya kegiatan yang dilakukan selain menyelesaikan skripsi. Pada penelitian ini, mahasiswa yang melakukan magang atau bekerja memiliki self-efficacy yang lebih rendah dibandingkan mahasiswa yang tidak memiliki kegiatan selain menyelesaikan skripsi. Hal itu sejalan dengan penelitian Hasanah (2011) yang menyatakan bahwa ketika mahasiswa yang tidak memiliki kegiatan selain berkuliah akan memiliki self-efficacy yang lebih baik jika dibandingkan dengan mahasiswa yang memiliki banyak kegiatan di luar perkuliahan. Mahasiswa lebih fokus ketika penyelesaian skripsi tidak memiliki kegiatan yang banyak, mahasiswa yang fokus pada penyelesaian skripsi akan 
memiliki keyakinan bahwa dirinya mampu untuk menyelesaikan skripsi (Hasanah, 2011).

Selama proses penelitian, peneliti menyadari masih terdapat banyak kekurangan dan keterbatasan. Penelitian ini hanya menggali mengenai prokrastinasi secara umum yang diasumsikan sebagai suatu perilaku negatif yang dimiliki oleh mahasiswa skrispi. Pada hal, berdasarkan penelitian yang dilakukan oleh Chu \& Choi (2005) diketahui bahwa prokrastinasi tidak selalu menunjukkan tindakan disfungsional. Menurut Chu \& Choi (2005), terdapat sebagian individu yang memang dengan sengaja menunda pekerjaannya karena mereka senang dengan tantangan yang ada sehingga dapat lebih menunjukkan hasil yang optimal (active procrastination). Lawan dari active procrastination adalah passive procrastination yang umumnya dilakukan oleh individu yang memiliki kecenderungan disfungsional.

Kelemahan lain dari penelitian ini adalah, saat penyebaran kuesioner, terdapat pertanyaan di data demografi mengenai "orang terdekat yang telat dalam menyelesaikan skripsi". Peneliti tidak menjelaskan definisi "telat", hal ini memungkinkan terjadi perbedaan persepsi antara peneliti dengan persepsi responden. Selain itu, pada lembar demografi terdapat tempat tinggal, peneliti berasumsi bahwa tempat tinggal merupakan bagian dari dukungan sosial. Pada kenyataannya tempat tinggal kurang menggambarkan dukungan sosial seseorang, sebaiknya langsung menanyakan hal yang terkait dengan dukungan sosial.

\section{Simpulan dan Saran}

Hasil penelitian menunjukkan tidak terdapat hubungan yang signifikan antara self-efficacy akademik dan prokrastinasi akademik pada mahasiswa yang sedang menyelesaikan skripsi.

Bagi peneliti selanjutnya yang tertarik untuk meneliti topik yang sama, disarankan untuk memperhatikan variabel lain yang dapat mempengaruhi prokrastinasi akademik, misalnya: personality based reason, task related reason, dan ability perception reason.

Penelitian selanjutnya dapat menggali lebih dalam mengenai active procrastination dan passive procrastination yang mungkin menunjukkan hubungan yang berbeda terhadap self-efficacy akademik mahasiswa.

Pada penelitian selanjutnya, saat penyebaran kuesioner peneliti dapat memberikan penjelasan mengenai suatu kalimat untuk menyamakan persepsi antara peneliti dengan responden.Selain saran yang sifatnya teoritis, peneliti memiliki saran yang bersifat praktis.

Bagi institusi pendidikan, sebaiknya bagi pihak institusi pendidikan dapat melakukan atau dapat mencegah hal-hal yang dapat mempengaruhi prokrastinasi akademik pada mahasiswa (seperti: usia, jenis kelamin, tahun masuk, tempat tinggal, dan kegiatan yang dilakukan selain menyelesaikan skripsi) saat menyelesaikan skripsi.

Bagi mahasiswa, selama menyelesaikan skripsi sebaiknya memiliki perencanaan waktu yang baik ketika dihadapi dengan banyak kegiatan atau organisasi untuk mengurangi perilaku prokrastinasi.

Bagi orangtua, dengan adanya kontrol yang kuat saat menyelesaikan skripsi akan menurunkan tingkat prokrastinasi pada mahasiswa. Orangtua disarankan untuk mengontrol anak yang sedang menyelesaikan skripsi untuk mengurangi perilaku prokrastinasi.

Bagi praktisi psikologi sekolah, Memberikan saran kepada institusi pendidikan untuk melakukan intervensi terkait dengan prokrastinasi akademik pada mahasiswa yang sedang menyelesaikan skripsi. Hal tersebut tidak hanya melihat self-efficacy akademik melainkan melihat faktor lain (personality based reason, task related reason dan ability perception reason) yang dapat berhubungan dengan 
prokrastinasi akademik. Sehingga dapat membantu mahasiswa yang mengalami hambatan ketika menyelesaikan skripsi.

\section{Daftar Pustaka}

Ahmaini, D. (2010). Perbedaan prokrastinasi akademik antara mahasiswa yang aktif dengan yang tidak aktif dalam organisasi kemahasiswaan pema USU. (Skripsi). Fakultas Psikologi Universitas Sumatera Utara, Medan.

Aini, A. N. (2011). Hubungan antara kontrol diri dengan prokrastinasi dalam menyelesaikan skripsi pada mahasiswa Universitas Muria Kudus. Jurnal Psikologi Pitutur, 1(2)

Bandura, A. (1997). Self-efficacy: The Exercise Of Control. New York: Freeman and Company

Chu, A. H. C. \& Choi, J. N. (2005). Rethinking procrastination: Positive effectsof "active" procrastination behavior on attitudes and performance. The Journal of Social Psychology, 145(3), $245-265$.

Fibrianti, I. D. (2009). Hubungan antara dukungan sosial orangtua dengan prokrastinasi akademik dalam menyelesaikan skripsi pada mahasiswa fakultas psikologi Universitas Diponegoro (Skripsi). Fakultas Psikologi Universitas Diponegoro, Semarang.

Fitriani, A. U. (2016). Peran self-efficacy for self-regulated learning ( $\mathrm{srl}$ ) dan srl dalam memprediksi perilaku prokrastinasi akademik pada mahasiswa yang sedang menyusun skripsi serta tinjauannya dalam perspektif Islam (Skripsi). Fakultas Psikologi Universitas YARSI, Jakarta.

Fuadi, R. (2013). Hubungan antara hope for success dan fear of failure dengan prokrastinasi pada mahasiswa Universitas Indonesia dalam mengerjakan skripsi. (Skripsi). Universitas Indonesia, Depok.
Hasanah, L. N. (2011). Self-efficacy dan motivasi berprestasi sebagai prediktor prokrastinasi akademik pada mahasiswa. Jurnal Psikologi, IV(2).

Julianda, B. N. (2012). Prokrastinasi dan self-efficacy pada mahasiswa fakultas psikologi Universitas Surabaya. Jurnal Ilmiah Mahasiswa Universitas Surabaya, 1(1).

Khusniatun. (2014). Hubungan antara resiliensi dan prokrastinasi akademik pada mahasiswa program studi psikologi fakultas ilmu sosial dan humaniora Universitas Islam Negeri Sunan Kalijaga Yogyakarta. Jurnal Psikologi, 2(2).

McCloskey, J. D. (2011). Finally, my thesis on academic procrastination (Thesis). The University of Texas, Texas.

Nuruddin, I. (2010). Hubungan antara selfefficacy dengan perilaku prokrastinasi akademik pada mahasiswa Al-Hidayah Wajak Malang (Skripsi). Fakultas Psikologi UIN Maulana Malik Ibrahim, Malang.

Rahmawati, D. A. (2011). Hubungan antara konsep diri akademik dan dukungan sosial teman dengan prokrastinasi akademik penulisan skripsi pada mahasiswa (Tesis) Universitas Gajah Mada, Yogyakarta.

Rauf, N. W. (2015). Hubungan antara academic self-efficacy dan kecenderungan mengalami academic burnout pada mahasiswa serta tinjauannya menurut agama Islam. (Skripsi). Universitas YARSI: Jakarta

Rohmatun. (2013). Hubungan self-efficacy dan pola asuh otoriter dengan prokrastinasi akademik pada mahasiswa. Jurnal Ecopsy, 1(1).

Schowenburg, H. C. \& Dewitte, S. (2002). Procrastination, temptations, and incentives: the struggle between the present and the future in procrastinators and the punctual. European Journal Of Personality, 16.

Siaputra, I. P. (2012). Subjective and projective measures of thesis writing 
procrastination: real world and the sims world. Anima Indonesian Psychological Journal, 26

Sokolowska, J. (2009). Behavioral, cognitive, affective and motivational dimensions of academic procrastination among community college students: A methodological approach. New York University

Steel, P. (2007). The nature of procrastination: A meta-analytic and theoretical of quintessential selfregulatiory failure. Psychological Bulletin, 133(1)
Wibowo, R. F. (2014). Self-efficacy dan prokrastinasi pada mahasiswa fakultas psikologi Universitas Surabaya. Jurnal Ilmiah Mahasiswa Universitas Surabaya, 3(1).

Zajacova, A., Scott M. L, et.al.. (2005). Self-efficacy, stress, and academic success in college. Research In Higher Education, 46(6). 